\title{
Perspektif Hukum Pidana Islam tentang $\because$ Penyelesaian Masalah Kejahatan secara Rekonsiliatif
}

\author{
M. Abdul Kholiq, AF
}

\begin{abstract}
In perspective Law of Islamic Criminal, reconciliation has been familiar through the concept Al-a'fwu 'uquubah. Islamic Reconciliation is only relevant to the certain felony cases namely qishash and it is different from jarimah hudud. The validity of reconciliation of Islam must be based on the certain requirements in order that the reconciliation created is the problem solving and executable as well.
\end{abstract}

\section{Pendahuluan}

Dewan Perwakilan Rakyat (DPR) membentuk Panitia Khusus untuk pembahasan Rancangan Undang-Undang tentang Komisi Kebenaran dan Rekonsiliasi (RUU- KKR) beberapa waktu yang lalu, wacana hakekat dan urgensi keberadaan komisi yang antara lain akan bertugas khusus menangani penyelesaian problem hukum pelanggaran Hak Asasi Manusia (HAM) berat melalui jalur ekstra yudisial, kembali menjadi perhatian publik.

Sesungguhnya gagasan tentang pembentukan KKR ini, pertama kali pernah mengemuka mengiringi datangnya era reformasi medio 1998. Pada waktu itu, persoalan transparansi dan demokratisasi yang menjadi jargon utama reformasi, telah mendorong sedemikian rupa terhadap para korban pelanggaran HAM berat dalam berbagai kasus masa lampau (era regim Orde Baru), untuk melakukan bermacam tuntutan. Seperti penyelenggaraan peradilan terhadap pelaku kejahatan HAM, pemberian kompensasi, restitusi maupun rehabilitasi terhadap para korban dan lain sebagainya demi untuk tegaknya jaminan atas pengakuan dan perlindungan HAM warga sipil.

Dalam merespon berbagai tuntutan di atas, kebijakan pemerintahan reformatif (baik era Habibie, Abdurrahman Wahid maupun Megawati), secara kategoris dapat dikelompokkan ke dalam dua hal. Pertama, terhadap kasus-kasus pelanggaran HAM masa silam (yakni sebelum lahirnya UU No. 26 Tahun 2000) yang masih dimungkinkan untuk diselesaikan secara yuridis, negara 
menanganinya dengan membentuk peradilan HAM Ad Hoc (In Court System). Contoh kategori kasus yang demikian ini iálah kasus Timor Timur pasca jajak pendapat dan kasus Tanjung Priok yang peradilannya sekarang sedang berlangsung. Kedua, terhadap kasuskasus pelanggaran HAM masa silam yang sekiranya sulit untuk ditangani melalui jalur peradilan (misalnya karena problem sulitnya pembuktian, "karena pertimbangan kemaslahatan dan keutuhan bersama sebagai bangsa dan lain-lain), penyelesaiannya didisain melalui jalur "Out Court System" (di luar lembaga peradilan). Untuk realisasi kebijakan kategori kedua inilah negara merencanakan membentuk suatu lembaga yang kemudian populer dengan sebutan Komisi Kebenaran dan Rekonsiliasi (KKR).'

Betapapun kehadiran lembaga serupa telah cukup banyak dikenal dan dipraktekkan di berbagai negara lain, namun bagi Indonesia dapat dikatakan sebagai hal baru. Oleh karena itu, tidak mengherankan jika di kalangan masyarakat luas timbul berbagai pertanyaan yang berkesan "menggugat" legitimasi dan justifikasi keberadaannya. Apakah secara teoritik, lembaga non hukum dapat diterima menjadi media penyelesaian masalah hukum? Sejauhmana kekuatan hukumnya? Bagaimana mekanisme prosedural yang harus diciptakan agar keputusan lembaga ini nantinya tidak hanya bersifat di atas kertas semata (non executable)?

Tulisan ini mencoba menjawab berbagai pertanyaan tersebut dengan sudut pandang hukum pidana Islam. Dalam konteks Indonesia, urgensi perspektif islam ini ialah untuk memberikan pemahaman sekaligus landasan justifikasi apakah ide pembentukan KKR sebagai alternatif penyelesaian masalah kejahatan HAM dengan jalur non hukum tersebut dapat dibenarkan oleh ajaran agama yang dianut oleh mayoritas bangsa Indonesia? Jawaban objektif proporsional atas kajian demikian ini menjadi penting agar UU KKR yang nanti akan dilahirkan benar-benar dapat berlaku efektif karena ada penerimaan secara sosiologis. ${ }^{2}$

${ }^{1}$ Bayangan tentang kesultan menggunakan prosedur hukum formal melalui jalur peradilan dalam menangani pelanggarän HAM masa lalu tampaknya juga telah menjadi kesadaran di hampir setiap negara yang sedang mengalami masa transisi yaitu dari situasi otoritarianisme menuju demokrasi. Menurut Kurt Jonassohn, ada berbagai sumber penyebab kesulitan seperti biaya gelar peradilan HAM yang sangat mahal, ingatan para saksi yang sudah tidak lengkap, atau banyaknya para saksi maupun pelaku yang sudah tua bahkan meninggal dunia dan lain sebagainya. Semua ini mendorong relevansinya ide altematif tentang Komisi Kebenaran dan Rekonsiliasi. Selengkapnya baca Kurt Jonassohn. dalam Suparman Marzuki, "Penyelesaian Pelanggaran HAM Masa Lalu Di Luar Pengadilan HAM: Pengalaman Beberapa Negara," Makalah disampaikan dalam Seminar Regional tentang Mencari Model Komisi Kebenaran dan Rekonsiliasi Indonesia, Dept. Pidana FH-Ull, tanggal 4 Oktober 2003.

2 Menurut Soerjono Soekanto, efektifitas beriakunya sualu aturan hukum (c.q UU), selain dipengaruhi oleh syarat adanya justifikasi filosofis dan yuridis juga harus terpenuhi syarat berupa justifikasi sosiologis. Selengkapnya baca Soerjono Soekanto, Penegakan Hukum (Jakarta: Bina Cipta, 1983, hlm. 29. 


\section{Al-'afwu 'anil 'Uquubah: Konsep Dasar Islam tentang Rekonsiliasi}

Dalam Ketentuan Umum pasal 1 angka 2 RUU KKR, disebutkan bahwa rekonsiliasi adalah hasil dari suatu proses pengungkapan kebenaran, pengakuan dan pengampunan melalui Komisi Kebenaran dan Rekonsiliasi dalam rangka menyelesaikan pelanggaran HAM yang berat untuk terciptanya perdamaian dan persatuan bangsa.

Berdasarkan ketentuan di atas dapat dipahami bahwa hakekat rekonsiliasi sesungguhnya merupakan upaya sekali gus media untuk menyelesaikan kasus kejahatan tertentu yakni berupa pelanggaran HAM berat (jadi tidak untuk semua kasus) dengan tidak melalui proses penuntutan hukum di pengadilan. Akan tetapi melalui suatu lembaga independen non pengadilan yang disebut Komisi Kebenaran dan Rekonsiliasi (KKR) dengan dasar atau prinsip "win-win solution".

Dikatakan demikian karena menurut penjelasan umum RUU KKR, rekonsiliasi ban dianggap terjadi secara sah jika pada satu pihak yaitu tersangka pelaku pelanggaran HAM mau mengakui kesalahannya, mau mengakui kebenaran fakta-fakta yang terungkap tentang pelanggaran HAM berat yang dilakukannya, mau menyatakan penyesalan atas perbuatannya serta bersedia meminta maaf kepada korban atau keluarga korban sebagai ahli warisnya. Sementara itu pada pihak yang lain yaitu korban atau keluarganya berkenan pula memberi maaf kepada pelaku. Jika kedua pihak sudah bersikap saling memaafkan, maka sebagai "reward"-nya, kepada pelaku dapat diberikan amnesti (pengampunan atas kejahatannya) dan kepada pihak korban atau keluarganya dapat diberikan kompensasi dan atau restitusi sebagai ganti rugi.

"Win-win solution" yang berbasis pemaafan ini, sasaran akhirnya adalah demi mewujudkan perdamaian serta persatuan dan kesatuan bersama sebagai bangsa. Jadi dengan kata lain, penyelesaian kejahatan HAM secara rekonsiliatif sama sekafi tidak dimaksudkan untuk membuka "luka lama" apalagi merupakan "ajang balas dendam". ${ }^{3}$

Dalam Islam, dasar-dasar dan orientasi tentang konsep rekonsiliasi di atas sesungguhnya dapat diketemukan pada salah satu ajarannya yang dikenal dengan sebutan "al-'afwu 'anil 'uquubah" (ampunan atas suatu hukuman).

\footnotetext{
${ }^{3}$ Penegasan bahwa media KKR sama sekali tidak dimaksudkan sebagai upaya membuka luka lama alau ajang balas dendam dari korban kepada pelaku kiranya menjadi penting. Karena di kalangan para pihak yang akan dijadikan tersangka pelanggaran HAM masa silam (terutama militer), banyak yang berpikir apriori seperti ini. Dalam konteks demikian, maka ada sementara pihak yang berpandangan bahwa hakekat penyelesaian kejahatan HAM melalui media KKR ini sesungguhnya merupakan bentuk penyelesaian perkara kejahatan secara kompromistis yaitu ketika jalur hukum maupun politis tidak memungkinkan diterapkan secara strick. Pandangan tersebut antara lain dapat dicermati dari pikiran Ifdhal Kasim, "Dilemma Komisi Kebenaran dan Rekonsiliasi" sebagaimana dikutip oleh Salman Luthan dalam "Anatomi RUUKKR," makalah disampaikan dalam Seminar Regional bertema Mencari Model Komisi Kebenaran dan Rekonsiliasi Indonesia, diselenggarakan oleh Dept. Pidana FH-Uil tanggal 4 Oktober 2003.
} 
Menurut Saamikh Sayyid Jaad, pada prinsipnya filosofi pemikiran yang mendasari konsep pemaafan atas hukuman adalah berkorelasi erat dengan falsafah penghukuman itu sendiri. ${ }^{4}$.

Dalam syariat Islam, tujuan penjatuhan hukuman (pidana) pada pelaku kejahatan setidaknya didasarkan atas 2 (dua) orientasi pokok. Pertama, orientasi yang bersifat umum yakni untuk mencegah timbulnya kerusakan 1 madlarat dalam kehidupan manusia dan untuk menciptakan kemaslahatan di dalamnya. Inilah inti dari al-maqaashidu at-tasyrityyah (tujuan pokok syariat Islam) yaitu "dar'ul mafaasidi wa jalbul mashaalihi". Kemudian orientasi tujuan pemidanaan kedua yang bersifat khusus ialah untuk pembalasan dan sekali gus pencegahan kejahatan (al-jazaa'u war raddu) serta untuk pengajaran/pendidikan dan kebaikan kehidupan bersama (at-ta'dieb/ at-tahdzieb wal. ishlah). ${ }^{5}$ Dasar-dasar dan orientasi penghukuman menurut Isiam ini antara lain dapat dicermati dari ketentuan alQuran surat al-Maaidah: 38, an-Nuur: 2, alBaqarah: 179 dan lain sebagainya.

Adapun makna pencegahan yang dimaksud di atas ialah menahan terpidana agar tidak mengulangi kejahatannya, di samping juga menahan orang lain (masyarakat luas) agar tidak mëlakukan kejahatan sebagaimana yang diperbuat terpidana.

Selain mencegah kejahatan, konsep tujuan penghukuman di atas juga mencerminkan adanya aspek perhatian syariat islam terhadap proses perbaikan diri pelaku kejahatan yang bersumber pada kesadarannya sendiri. Itulah sebabnya ketentuan pidana dalam Islam tidak diatur dengan menggunakan "pola antara" seperti pada KUHP ataupun pola waktu yang limitatif. Hal ini karena Islam mengarahkan agar tercegahnya pelaku dari berbuat jahat diharapkan bukan karena ia takut akan terkena -hukuman, melainkan lebih karena kesadarannya sendiri (setelah merenung) terhadap buruknya kejahatan yang harus dibenci dan dijauhi. Sebab kejahatan merupakan hal yang dapat menjauhkan seorang manusia dari memperoleh ridlo Allah SWT sebagai tujuan hidup hakiki. Kesadaran macam inilah yang sesungguhnya menjadi idaman para sarjana hukum positif.

Di samping mengusahakan perbaikan pribadi pelaku kejahatan, tujuan penghukuman dalam islam yang berorientasi "ishlah" di atas juga mengandung makna bahwa dengan hukuman itu Islam ingin membentuk pula suatu masyarakat yang baik yang dilandasi rasa saling menghormati dan mencintai diantara sesama anggotanya dengan mengetahui serta memahami batas-batas tentang hak-hak dan kewajibannya.

Oleh karena tujuan pokok penghukuman adalah pembalasan, pencegahan, pengajaran dan kemashlahatan yang harus diupayakan perwujudannya secara utuh (integral), maka bentuk dan bobotnya tidak selalu harus berat

' Saamikh Sayyid Jaad, Al-'Afwu 'Anil 'Uquubati fil Fighil Islaamie wal Qonuunil Wadlie (Kairo, Mesir: Daarul 'Ilmi Liththiba'ati Wansyri, 1983), hlm.12.

${ }^{5}$ Baca Ahmad Hanafi, Asas-Asas Hukum Pidana Islam (Jakarta: Penerbit Bulan Bintang, 1990), him. 255257. Lihat juga Ahmad Djazuli, Fiqh' Jinayat (Upaya Menanggulangi Kejahalan dalam Islam) (Jakarta Rajawali Pers, 1996), hlm. 26-27. 
namun juga tidak serta merta berarti ringan. Jadi, cukup sedemikian rupa yang sekiranya dapat mengantarkan terwujudnya tujuantujuan tersebut,yaitu: (a) memiliki daya prevensi terhadap kerusakan yàng timbul akibat kejahtan (raddul mafsadah), (b) relatif sebanding/seimbang dengan kejahatan pelaku (al-'adaalah bil musaawah) dan (c) dapat mendukung terwujudnya kemashlahatan baik bagi pelaku kejahatan maupun masyarakat pada umumnya (al-'uquubah ma'al mashlahah). ${ }^{6}$

Apabila konfigurasi pemikiran tentang tujuan pidana dan pemidanaan di atas dicermati, maka dapat dipahami bahwa keberadaan hukuman (pidana) sesungguhnya hanya merupakan suatu alat atau media untuk mewujudkan tujuan-tujuan tersebut, bukan satu-satunya. Dengan demikian, jika sekiranya suatu kejahatan dapat diselesaikan melalui ajaran "al-'afwu 'anil 'uquubah" (yakni dengan tidak menjatuhkan hukuman melainkan dengan menerapkan perdamaian berbasis pemaafan) dan dengan itu pula berbagai tujuan penghukuman di atas pun sudah dapat diwujudkan, maka secara konseptual ajaran pemaafan dalam rangka mewujudkan perdamaian ini juga harus dipandang sebagai sesuatu yang memiliki justifikasi.

Islam sebagai agama perdamaian, dalam banyak ayat al-Quran memang sangat menekankan perlunya ummat manușia terutama muslim menampilkan sikap-sikáp pemaaf sebagai salah satu sendi perdamaian itu sendiri. Dalam surat as-Syuura ayat $39-40$ misalnya, Allah SWT menegaskan: "Walladziena idza ashaabahumul baghyu hum yantashiruun. Wa jazaa'u sayyiatin sayyiatun mitsluhaa. Faman 'afaa wa ashlaha faajruhuu 'alallaahr'.

Berdasarkan ayat ini diperoleh pemahaman bahwa sesungguhnya ketika seseorang mengalami mushibah menjadi korban atas serangan suatu kejahatan, pada prinsipnya ia memang boleh bahkan harus membela diri. Selain itu, sudah sepantasnya pula suatu kejahatan dibalas dengan kejahatan yang serupa (yakni melalui penghukuma!: yang setimpal). Namun demikian, jika pihak yang terdholimi atau menjadi korban lebih. memilih sikap sabar dan memaafkan serta tetap berbuat baik kepada orang yang telaí. melakukan kejahatan kepada dirinya, maka di mata Allah SWT, sikap demikian itu justru dipandang lebih baik sehingga pahalanya pun dinyatakan sangat spesial dan menjadi tanggungan Allah secara langsung (faajnhuu 'alallaahi).

Dalam ayat lain yakni Q.S al-Baqarah ayat 237, sikap memaafkan atas kesalahan orang ini bahkan dinyatakan sebagai perbuatan yang dapat mendekatkan pada derajat/kedudukan

${ }^{6}$ Fikri Anmad 'Akkaaz, Falsafatu Al-'Uquubati fis Syari'ati Al'lslaamiyati wal Qonuuni al-Wadlie, (Arab: Syirkah Maktabah 'Akkaadz, Al-Mamlakah Al-'Araabiyyah As-Su'udiyyah, 1982), hlm.49-55. Dalam bahasa yang lain, Ibrahim Hussein juga menyatakan bahwa pidana itu hendaknyamemilikikekuatan fungsional sebagai media pencegah pengulangan kejahatan oleh pelaku dan media pemberian pertindungan kepada masyarakat (fungsi Zawaajir) serta dapat pula menjadi sarana agar pelaku benar-benar bertobat dan kembali menjadi hamba Allah yang baik (fungsi Jawaabi). Selengkapnya baca Ibrahin Hussein, "Jenis-jenis Hukuman dalam Hukum Pidana Islam (Re-interpretasi terhadap Pelaksanaan Aturan)," Artikel sumbangan dalam buku Wacana Baru Fiqih Sosial, Memperingati Usia 70 tahun KH. Ali Yafie (Bandung: Mizan, 1997), hlm. 100. 
sebagai seorang muttagie (Waantafuu aqrabu littaqwaa). Oleh karena itu, sudah tepat kiranya sikap memaafkan ini juga sekali gus dinyatakan Allah SWT (Q.S Ali Imran: 133-134) sebagai salah satu ciri atau syarat bagi seseorang yang benar-benar ingin disebut sebagai orang yang bertaqwa dan berhak memperoleh "reward" Allah berupa maghfirah dan surga-Nya (Wa saari'uu ilaa maghfiratin min rabbikum wa. jannatin 'ardluha assamaawaati wal ardli u'iddat lil muttaqien. Alladziena yunfiquuna fis sarraai wad dlarraai wal kaadhimiena al-ghaidha wal 'aafiena. 'aninnaas. Wallaahu yuhibbul muhsinien).

Menurut Ahmad Fathi Bahantsi, tujuan ajaran memaafkan (baca: rekonsiliasi) dalam penyelesaian suatu kejahatan yang sangat ditekankan oleh Islam di atas ialah agar dalam kehidupan bersama tidak berkembang sikap pemusuhan yang tak berkesudahan akibat saling membalas dendam. Itulah sebabnya, walaupun hukuman balasan setimpal (qishash) dalam suatu kasus pembunuhan misainya memang sangat dibenarkan, akan tetapi konseptualisasi dan prakteknya diarahkan agar hal itu dijadikan sebagai alternatif terakhir. Karena yang lebih diutamakan bahkan dianjurkan sebenarnya ialah memaafkan pelaku kejahatan baik disertai dengan tuntutan diyat (ganti rugi) ataupun tidak sama sekali. ${ }^{7}$

Di samping itu dalam perspektif akhlaq. urgensi ajaran tersebut juga mengandung maksud agar dapat menjadi media dalam membangun serta menumbuhkan sifat kebajikan dalam diri manusia secara umum maupun dalam dir korban atau keluarganya secara khusus. Adapun rasionalisasi sikap memaafkan dikatakan sebagai kebajikan adalah karena orang yang memaafkan itu sesungguhnya merupakan orang yang sedang berusạha untuk bersikap arif/bijak dengan tidak menuntut hukum yang seharusnya menjadi haknya. Tentu sikap demikian tidak semua orang mampu melakukannya, dan inilah yang menjadikan seorang pemaaf layak disebut sebagai bijak. Hal tersebut berbeda dengan sikap seseorang yang di dalam menghadapi problem dirinya sebagai korban kejahatan lebih memilih menuntut secara hukum. Meskipun penggunaan hak demikian ini sangat absah, namun itu adalah hal yang wajar dan semua orang tentu mampu melakukannya. Karena sudah menjadi karakter manusia bahwa pada saat dirinya disakiti seseorang kecenderungannya ialah ingin membalas dendam (minimal secara setimpal) terhadap pelaku.

Mengingat begitu terhormatnya seorang yang bijak karena pemaaf tersebut, maka tidak mengherankan jika Nabi Muhammad dalam berbagai sabdanya sangat menekankan hal ini seperti terlihat dalam hadits-hadits berikut: a). "Tidaklah seseorang yang mengampuni suatu perbuatan yang dhalim itu melainkan Allah akan menambah kepadanya kemuliaan" (H.R Imam Ahmad, Muslim dan Tirmidzi).

${ }^{7}$ Ahmad Fathi Bahantsi, Al-Qishashu fil Fiqhi Al-Islamie, (Kairo:As-Syirkah Al-'Arabiyah Lit-Thiba'ah wan Nasyr, 1964), hlm. 67-191. Lihat juga Saamikh Sayyid Jaad, op cit, hlm. 21-51 dan Sayyid Saabiq, Fiqih Sunnah, Jilid X, (Bandung: Al-Ma'arif, 1987), hlm. 30-90. 
b). "Tidaklah seseorang itu ditimpa mushibah sesuatu pada anggota badan (fisik)-nya lalu karena itu ia bersedekah (dalam konteks qishash artinya memaafkan penulis), melainkan Allah akan mengangkat derajatnya dan menghapuskan kesalahannya" (H.R Ibnu Maadjah dan Tirmidzi).

cj. "Barangsiapa ditimpa mushibah dengan tertumpahnya darah atau Juka, maka ia boleh memilih salah satu di antara tiga kemungkinan yaitu menuntut qishash, mengambil diyat atau memaafkan" (H.R Imam Ahmad, Ibnu Maadjah dan Abu Daud).

Sehubungan dengan ajaran al-'afwu 'anil 'uquubah di atas, sangat mungkin muncu! suatu pertanyaan mendasar, apakah dengan pengampunan tersebut tidak dikhawatirkan akan berdampak pada masalah keamanan dan ketenteraman masyarakat serta berkesan menguntungkan bahkan memanjakan pelaku kejahatan sehingga mengaburkan efek penjeraan dari sebuah penyelesaian masalah kejahatan?

Untuk menjelaskan masalah tersebut, perlu diketahui bahwa ajaran rekonsiliasi dalam Islam ini aplikasinya tidaklah bersifat serta merta (tanpa syarat) dan dapat berlaku mutlak untuk semua kasus kejahatan.

Berdasarkan nash al-Quran dan al-hadits diketahui bahwa pada prinsipnya, penyelesaian kejahatan dengan rekonsiliasi ini hanya dapat diterapkan pada kasus jarimah qishash baik berupa penganiayaan maupun pembunuhan. ${ }^{8}$
Adapun dasar-dasar nash yang dimaksứd antara lain dapat dicermati dari kutipan-kutipàn berikut ini:

a) Yaa ayyuhalladziina aamanuu kutiba 'alaikumul qishashu fil qotlaa Faman 'ufiya lahuu min akhiihi syai'un fattibaa'un bil ma'ruufi wa adaa'un ilaihi biihsaanin ......... al-ayah (Q.S al-Baqarah : 178).

b) Maa rufia ilaihi syai'un fii qishashin illaa umira bihi bil 'afwi (al-hadits).

c) Man qutila lahu qotielun fahuwa bikhoirin nadharaini baina an ya'khudza ad-diyyata wa baina an ya'fuwa (al-hadits).

Selain kasus jarimah qishash, upaya rekonsiliasi juga dapat diterapkan pada beberapa jenis tertentu dari jarimah huduu Hal ini dapat dilihat dari hadits nabi yang menyatakan: "Ta'aful huduuda fiima bainikum famaa balaghanie min haddin faqad wajaba". Terjemahan bebas hadits ini ialah "Hendaklah di antara kalian yang terlibat dalar: kasus jarimah hudud saling memaafkan sebelum perkaranya sampai kepadaku (sebagai hakim -penulis). Sebab jika tidak demikian (artinya perkara sudah terlanjur berproses di pengadilan) maka aku terikat pada kewajiban untuk menerapkan ketentuanketentuan hudud yang ada".

Berbagai ketentuan nash di atas, menunjukkan bahwa konsep rekonsiliasi lslam hanya dapat diterapkan pada kasus-kasus jarimah yang di dalamnya ada korban yang bersifat langsung atau individual (direct victim / individual victim). Pemahaman demikian ini

${ }^{8}$ Lihat Marsum, Jinayat (Hukum Pidana Islam) (Yogyakarta: Penerbit Perpustakaan Fakultas Hukum Uil, 1988), hlm. 126. Lihat juga Haliman, Hukum Pidana Syariat Islam Menurut Ajaran Ahlus Sunnah (Jakarta: Bulan Bintang, 1971), him. 199. 
didasarkan pada disebutnya beberapa kasus di atas yang oleh Allah SWT atau Nabi dimungkinkan bahkan dianjurkan untuk diselesaikan secara damai dan berbasis maaf (rekonsiliasi).

Dalam jarimah qishash misalnya, tentu kasus ini ada korban langsungnya yakni orang yang dibunuh atau orang yang dianiaya. Demikian juga dalam jarimah hudud tertentu, seperti qodzaf (menuduh zina tanpa bukti) dan khirobah (merampok). Dalam kedua kasus ini korban langsung / individualnya adalah orang yang dituduh tanpa bukti (korban fitnah) atau orang yang dirampok. Penegasan konsep rekonsiliasi hanya pada jarimah tertentu yang terdapat korban bersifat langsung tersebut secara logika dapat diterima. Karena konsep tersebut berkait erat dengan siapa pihak yang nantinya sungguh-sungguh berhak menyatakan pengampunan atau pemaafan pada pelaku kejahatan. Tentu menjadi sangat mustahil untuk menciptakan rekonsiliasi suatu kasus jika dalam kasus bersangkutan tidak ada korbannya (victimless). ${ }^{9}$

Jadi, karena penerapan ajaran al-'afwu 'anil 'uquubah (rekonsiliasi) ini bersifat limitatif (tidak untuk semua kasus kejahatan), maka kekhawatiran mengenai lemahnya fungsi hukum dan sanksinya sebagai salah satu norma pengatur kehidupan masyarakat, kiranya tidak perlu menjadi sesuatu yang mencemaskan. Apalagi dalam Islam, implementasi atas praktek rekonsiliasi ini juga harus memenuhi beberapa persyaratan tertentu sebagai berikut: ${ }^{\text {to }}$

a) Pengampunan harus diberikan oleh orang-orang/pihak-pihak yang memang berhak memberi ampunan (korban jarimah atau ahli warisnya)

b) Korban atau ahli waris yang memberi ampunan harus dalam kondisi 'aqil dan baligh (sehat akalnya dan dewasa)

c) Pengampunan tidak boleh terjadi atas dasar paksaan atau rekayasa

d) Pengampunan harus dengan kata-kata / kalimat yang shorih (jelas)

e) Pengampunan (terutama dalam kasus jarimah qishash) harus dilegitimasi oleh putusan pengadilan agar executable.

Sejumlah syarat mengenai sahnya rekonsiliasi menurut Islam di atas sangat penting untuk diimplementasikan agar upaya rekonsiliasi dapat benar-benar menjadi media .penyelesaian masalah yang tidak menyisakan masalah atau justru malah menimbulkan masalah. Sebab jika syaratsyarat tersebut tidak dipenuhi maka yang lahir nanti hanyalah sebuah rekonsiliasi yang semu."

${ }^{\theta}$ Konsep rekonsiliasi Islam yang dibatasi pemberlakuannya hanya untuk beberapakasus jarimah (kejahalan) di atas, tampaknyajuga sejalan dengan ketentuan yang dirancang dalam RUUKomisi Kebenaran dan Rekonsilisi Indonesia yang juga hanya dapat diterapkan sebagai alternatif untuk menyelesaikan kasus kejahatan HAM berat tertentu (Crime Against Humanity dan Genocide Crime) itupun yang terjadi pada masasa lalu yakni sebelum lahirnya UU No. 26/2000 tentang Pengadilan HAM.

${ }^{\text {to }}$ Saamikh Sayyid Jaad, op cit, hlm. 26-38.

"Dalam konteks indonesia, contoh rekonsiliasi semu yang belakangan memang menimbulkan masalah baru tersebut antara lain dapat dicermati dalam kasus Jendral (Purn.) Tri Sulrisno yang beberapa waktu lalu diberitakan ingin melakukan ishlah (baca: rekonsiliasi) dengan keluarga korban peristiwa Tanjung Priok. Akan tetapi ishlah yang diterapkan Tri Sutrisno akhimyamengalami kegagalan karena dia upayakan melalui rekayasa yakni dengan memberikan harapan atau janji kepada sejumlah orang yang diklaim sebagai mewakili keluarga 
Rekonsialiasi yang terjadi antara tersangka pelaku kejahatan dengan orang yang bukan merupakan korban sesungguhnya selain tidak sah, hakekatnya hanya akan menyimpan bom waktu berupa dendam kesumat dari para korban kejahatan sebenamya yang dapat meledak setiap saat.

Begitupun dengan rekonsiliasi yang terjadi karena suatu rekayasa apalagi karena paksaan. Sekalipun hal itu dilakukan dengan para korban kejahatan yang sesungguhnya, namun secara yuridis agama memandang tidak sah. Sebab perbuatan hukum seorang anak kecil yang belum dewasa (sehingga mudah direkayasa) atau perbuatan hukum seorang dewasa akan tetapi dilakukan dalam kondisi terpaksa, hakekatnya tidak dianggap sebagai suatu perbuatan hukum yang memiliki konsekuensi. Dalam hubungan ini Nabi Muhammad SAW menegaskan bahwa: "Rufi'a al-qalamu 'an tsalaatsin: 'anin-naaimi hatta yastaiqadha, wa'anish-shabie hatta yablugha, wa'anil junuuni hatta yastaiqadha". ${ }^{12}$
Artinya, diangkat catatan pena dari seseorang (dalam arti amai perbuatan seseorang tidak akan ditulis/dianggap tidak mempunyai akibat hukum) dalam tiga perkara. Perkara tersebut adalah perbuatan orang yang sedang tidur hingga ia terbangun, perbuatan anak yang masih kecil hingga ia dewasa dan perbuatan orang yang sedang gila hingga ia sadar kembali/sembuh. Dalam hadits yang lain Nabi Muhammad SAW juga menyatakan: 'Rufi'a alqalamu 'an ummatie tsalaatsatun: al-khatha'u wan-nisyaanu wa mastukrihuu "alaihi" ${ }^{13}$ Artinya, diangkat catatan pena dari salah satu di antara tiga golongan umatku (maksudnya perbuatan tiga golongan manusia berikut ini dianggap tidak memiliki konsekuensi hukum apapaun). Yaitu perbuatan orang yang terjaci karena khilaf, lupa dan karena ada suatu paksaan. ${ }^{14}$

Secara logika, tidak adanya konsekuensi hukum atas perbuatan orang-orang sebagaimana disebutkan dalam kedua hadits di atas memang sangat masuk akal dan wajar.

korban bahwa jika mereka mau memaafkannya (idak menuntut secara hukum) maka akan diberi sejumlah uang sebagai kompensasi dan akan ditempatkan sebagai pekerja di sejumlah pabrik tertentu. Jadi terciptanya ishlah tersebut tidak didasari oleh kemauan atau keikhlasan keluarga korban. Akibat kegagalan rekonsiliasi itu pun kita semua dapat melihat bahwa akhimya kasus Tanjung Priok tersebut sekarang tetap digelar persidangannya di Pengadilan HAM ad hoc.

${ }^{12}$ Hadits Riwayat Imam Ahmad ibnu Hambal dari istri Nabi Muhammad SAW bernama 'Aisyah binti Abu Bakar radliyallaahu 'anha.

${ }^{13}$ Hadits Riwayat Imam Bukhoridan Imam Muslim dari sahabat Nabi Muhammad SAW bernama Unar ibnu Khatthab radliyallaahu 'anhu.

"Khusus mengenai perbuatan orang yang terpaksa yang oleh islam dipandang tidak ada konsekuensi hukum apapun juga ditegaskan oleh Allah SWT sebagaimana dapat dicermati dari firman-Nya dalam Q.S alBaqarah: 173 yang berbunyi: "Faman idthurra ghaira baaghin wa laa 'aadin falaa itsma 'alaihih. Innallaaha ghafuurun rahiem" Artinya, barang siapa dalam keadaan terpaksa melakukan suatu perbuatan (sekalipun hal itu sangat terlarang menurut syarial -pen.) sedangkan ia sama sekali lidak menginginkannya dan tidak pula melampaui batas dalam berbuat, maka tidak ada dosa baginya. Sesungguhnya Allah maha Pengampun lagi maha Penyayang. 
Sebab anak kecil adalah sosok manusia yang sama sekali belum menyadari benar tentang apa yang diperbuatnya. Begitu pula orang yang dipaksa, adalah merupakan sosok manusia yang dalam berbuatnya sama sekali tidak didasari hak khiyar (kebebasan) di mana hal ini sangat penting untuk menentukan ada tidaknya tanggung jawab hukum bagi yang bersangkutan.

Selanjutnya mengenai syarat sahnya pengampunan/maaf (baca: rekonsiliasi) yang oleh ajaran Islam ditegaskan harus dilegitimasi melalui putusan pengadilan, inipun menjadi sangat penting supaya pemilihan serta penerapan alternatif penyelesaian kejahatan melalui rekonsiliasi tersebut benar-benar dapat dijalankan (executable). Sebab jika tidak demikian, model rekonsiliasi hanya akan menjadi konsep-konsep penyelesaian kejahatan di atas kertas semata dan sama sekali tidak ada yang menjamin atau memaksa untuk realisasinya. Terutama jika terjadi salah satu pihak mengingkari kesepakatan rekonsiliatif yang telah dibuatnya.

Dalam konfigurasi berpikir yang demikian ini, maka RUU KKR mendatang yang dikonsepkan sebagai institusi alternatif penyelesaian kejahatan HAM secara murni dalam arti tidak membutuhkan lagi peran pengadilañ, kiranya periu dikaji ulang.

\section{Simpulan}

Berdasarkan seluruh uraian terdahulu, maka dapat ditegaskan beberapa pokok kesimpulan mengenai perspektif Hukum Pidana Islam tentang Rekonsiliasi sebagai alternatif penyelesaian masalah kejahatan sebagai berikut:

1. Pada prinsipnya Islam mengenal dan mengajarkan pula penyelesaian masalah kejahatan secara rekonsiliatif yaitu melalui konsep yang disebut dengan istilah " $A$ 'afwu 'anil 'uquubah".

2. Rekonsiliasi Islam hanya berlaku untuk kasus-kasus kejahatan tertentu yaitu qishash dan beberapa jenis dari jarimah hudud.

3. Keabsahan Rekonsiliasi Islam harus didasarkan pada syarat-syarat tertentu dengan tujuan agar rekonsiliasi yang tercipta benar-benar menyelesaikan masalah dan sekaligus executable.u

\section{Daftar Pustaka}

'Akkaaz, Fikri Ahmad, Falsafatu Al-'Uquubati fis Syariati Al-Islamiyyati wal Qonuuni Al-Wadl'ie, Arab: Syirkah Maktabah 'Akkaadz, Al-Mamlakah Al-'Arabiyyah As-Su'udiyah, 1982.

Bahantsi, Ahmad Fathi, Al-Qishashu fil Fighil Islamie, Kairo:As-Syirkah Al-'Arabiyyah Lith-Thiba'ah wan Nasyr, 1964.

Djazuli, Ahmad, Fiqih Jinayat (Upaya Menanggulangi Kejahatan dalam Islam), Jakarta: Rajawali Pers, 1996.

Haliman, Hukum Pidana Syari'at Islam Menunut Ajaran Ahlus Sunnah, Jakarta: Bulan Bintang, 1971.

Hanafi, Ahmad, Asas-Asas Hukum Pidana Islam, Jakarta: Bulan Bintang, 1990.

Hussein, Ibrahim, "Jenis-Jenis Hukuman Dalam Hukum Pidana Islam (ReInterpretasi terhadap Pelaksanaan Aturan)," artikel sumbangan dalam buku Wacana Baru Fiqih Sosial, - Bandung: Mizan, 1997. 
Jaad, Saamikh Sayyid, Al-'Afwu 'Anil 'Uquubati fil Fiqhil Islamie wal Qonunil Wadlie, Kairo: Daarul 'Ilmi Lith-Thiba'ati wan Nasyri, 1983.

Luthan, Salman, "Anatomi RUU Komisi Keberiaran dan Rekonsiliasi, "Makalah disampaikan dalam Seminar Regional bertema Mencari Model Komisi Kebenaran dan Rekonsiliasi Indonesia, Dept. Pidana FH-Ull, Yogyakarta, tanggal 4 Oktober 2003.

Marsum, Jinayat (Hukum Pidana Islam), Yogyakarta: Penerbit Perpustakaan Fakultas Hukum UII, 1988.

Marzuki, Suparman, "Penyelesaian
Pelanggaran HAM Masa Lalu Di Luuar Péngadilan HAM: Pengalaman Beberapa Negara," Makalah disampaikan dalam Seminar Regional bertema Mencari Model Komisi Kebenaran dan Rekonsiliasi Indonesia, Yogyakarta: Dept. Pidana FH-UII, tanggal 4 Oktober 2003.

Saabiq, Sayyid, Fiqih Sunnah (Terjemahan), Jilid X, Bandung: Al-Ma'arif, 1987.

Soekanto, Soerjono, Penegakan Hukum, Jakarta: Bina Cipta, 1983.

UU No. 26/2000 tentang Pengadilan Hak Asasi Manusia.

RUU Komiši Kebenaran dan Rekonsiliasi. 808080 